\title{
Metallothionein Suppresses the Formation of 8-Hydroxy-2'- Deoxyguanosine in DNA Induced by Ferric Nitrilotriacetate in Vitro
}

\author{
Kyong-Son Min,* Taeko Horie, Noriko Tetsutchikawahara, and Satomi Onosaka \\ Faculty of Nutrition, Kobe Gakuin University, 518 Arise, Ikawadani-cho, Nishi-ku, Kobe 651-2180, Japan
}

(Received March 16, 2005; Accepted April 8, 2005; Published online April 11, 2005)

\begin{abstract}
Metallothionein (MT) is endowed with strong antioxidant and nucleophilic properties and is found not only in the cytosol but also in the nucleus. To investigate whether MT can directly protect against oxidative DNA damage in the nucleus, the effect of MT on 8-hydroxy-2'-deoxyguanosine (8-OHdG) formation induced by ferric nitrilotriacetate (Fe-NTA) was studied using purified MT or the primary cultures of MTenriched hepatocytes. The level of 8-OHdG was increased in a dose-dependent fashion by incubation of salmon sperm DNA with Fe-NTA in the presence of hydrogen peroxide. Addition of purified MT at $12.5 \mu \mathrm{M}$ to its incubation mixture resulted in a decrease of the 8-OHdG content in DNA by approximately $50 \%$. In the primary cultures of control hepatocytes, treatment of Fe-NTA at $200 \mu \mathrm{M}$ resulted in significant decreases in cell survival and an increased in the concentration of 8-OHdG following depletion of glutathione. However, these toxic effects of Fe-NTA were modulated in MT-enriched cells. These results suggest that MT may protect DNA against radical attack as a cellular radical scavenger.
\end{abstract}

Key words — metallothionein, hydroxyl radical, oxidative DNA damage, 8-hydroxy-2'-deoxyguanosine, ferric nitrilotriacetate

\section{INTRODUCTION}

Metallothionein (MT) is a small, cysteine-rich metal-binding protein. Studies showing that MT might act as a cellular antioxidant ${ }^{1,2)}$ and that MT levels are elevated during various oxidative stresses and following injection of prooxidant chemicals ${ }^{3-5}$

\footnotetext{
*To whom correspondence should be addressed: Faculty of Nutrition, Kobe Gakuin University, 518 Arise, Ikawadani-cho, Nishi-ku, Kobe 651-2180, Japan. Tel.: +81-78-974-1551; Fax: +81-78-974-5689; E-mail: min@ nutr.kobegakuin.ac.jp
}

suggest the MT gene may be redox-sensitive. Although typical antioxidant enzymes such as catalase, glutathione peroxidase and superoxide dismutase are cytosolic proteins, MT is found not only in cytosol but also in the nucleus. ${ }^{6,7)}$ Kumari et al. (2000) used electron spin resonance technology to provide direct evidence that both MT-I and II isoforms are able to protect against diphenyl picrylhydrazyl radicals, hydroxyl radicals, superoxides, and other reactive oxygen species. ${ }^{8)}$ Moreover, either overexpression or underexpression of MT results in differential resistance to the DNA-strand-breaking activity, but not to the detrimental action of $\mathrm{H}_{2} \mathrm{O}_{2}$, suggesting that MT's antioxidant properties may play an important role in the nucleus.9)

Reactive oxygen species (ROS) such as superoxide radicals and $\mathrm{H}_{2} \mathrm{O}_{2}$ are produced during normal cellular process. Excess generation of these species results in damage to biological macromolecules such as DNA. These species produce a unique spectrum of DNA lesions consisting of single and double strand breaks, modified bases, abasic sites, and DNA-protein cross-links. In an aqueous in vitro system, Abel and de Ruiter demonstrated that MT can inhibit Fe-EDTA induced DNA damage. ${ }^{10)}$ Further, Cai et al. have shown that MT inhibits DNA damage induced by $\mathrm{Cu}$-ascorbate- $\mathrm{H}_{2} \mathrm{O}_{2}$, but does not inhibit DNA damage induced by $\mathrm{Fe}^{3+}$ and $\mathrm{Fe}$-ascorbate- $\mathrm{H}_{2} \mathrm{O}_{2}{ }^{11)}$ In addition, they demonstrated that MT, in particular bound to $\mathrm{Zn}$, acts as a high-capacity antioxidant able to protect radiation-induced DNA damage. ${ }^{12)}$ MT can also protect DNA from oxidative attack by microsomes, but not in presence of adriamycin-Fe. ${ }^{13)}$

Nitrilotriacetic acid (NTA) is a synthetic chelating agent that has been used in various countries as a constituent in detergents. Ferric NTA (Fe-NTA) catalyzes the formation of $\cdot \mathrm{OH}$ from $\mathrm{H}_{2} \mathrm{O}_{2}$ as below. ${ }^{14}$ 


$$
\begin{aligned}
& \mathrm{Fe}^{3+}-\mathrm{NTA}+\mathrm{H}_{2} \mathrm{O}_{2} \rightarrow \mathrm{Fe}^{2+}-\mathrm{NTA}+\mathrm{O}_{2}^{-}+2 \mathrm{H}^{+} \\
& \mathrm{Fe}^{3+}-\mathrm{NTA}+\mathrm{O}_{2}^{-} \rightarrow \mathrm{Fe}^{2+}-\mathrm{NTA}+\mathrm{O}_{2} \\
& \mathrm{Fe}^{2+}-\mathrm{NTA}+\mathrm{H}_{2} \mathrm{O}_{2} \rightarrow \mathrm{Fe}^{3+}-\mathrm{NTA}+\cdot \mathrm{OH}+\mathrm{OH}^{-}
\end{aligned}
$$

The high rate of $\bullet \mathrm{OH}$ generation makes the $\mathrm{Fe}$ NTA $/ \mathrm{H}_{2} \mathrm{O}_{2}$ system a good paradigm for the study of oxidative stress by $\cdot \mathrm{OH}$. We have previously demonstrated that MT can suppress rasDNA strand scission. ${ }^{15)}$

DNA damage is often measured by loss of fluorescence of DNA binding to ethidium bromide and by increased DNA mobility in agarose gel electrophoresis. These methods are semiquantitative and can be affected by protein-DNA crosslinks. Another more quantitative method to assess damage is to measure specific oxidative DNA base modifications. ${ }^{16,17)} 8$-Hydroxy-2'-deoxyguanosine $(8-\mathrm{OHdG})$ is one of the best-characterized base modifications and its levels are increased after exposure to a variety of carcinogens, such as ionizing radiation and Fe-NTA in animals. ${ }^{18,19)}$ To investigate the protective effects of MT on DNA damage induced by oxidative stress, we studied effect of MT on formation of 8-OHdG induced by Fe-NTA in salmon DNA fragment and primary cultures of hepatocytes.

\section{MATERIALS AND METHODS}

Animals — Male rats (Wistar strain) 8 weeks old were purchased from Nihon SLC (Shizuoka, Japan). Rats were maintained on a 12-hr light-dark cycle and given food and water ad libidum (Type MF, Oriental Yeast, Osaka, Japan). All animal experiments were carried out under the control of the Animal Research Committee, in accordance with the Guidelines on Animal Experiments in Kobe Gakuin University and Japanese Government Animal Protection and Management Law (No. 105).

Chemicals — Salmon sperm DNA was obtained from Funakoshi (Tokyo, Japan). Ferric chloride, $30 \%(\mathrm{w} / \mathrm{v}) \mathrm{H}_{2} \mathrm{O}_{2}$, alkaline phosphatase and all chelating agents were purchased from Nacalai Tesque (Osaka, Japan). Nuclease $\mathrm{P}_{1}, 8-\mathrm{OHdG}$ and organic solvents for HPLC were purchased from Wako Pure Chemical Industries Ltd. (Osaka, Japan). Insulin, trypsin inhibitor (type II-S), and collagenase (type I) were obtained from Sigma. Dulbecco's Modified Eagle Medium (DMEM) was obtained from Nissui Pharmaceutical Co. Ltd. (Tokyo, Japan). Gentamicin sulfate was acquired from Shering-Plough Co. Ltd. (Osaka, Japan). DL-Buthionine (S,R)sulfoximine (BSO) was obtained from Aldrich
Chem. Co. (Milwaukee, WI, U.S.A.). Cell Titer 96 Aqueous kit and 8-OHdG check ELISA kit were obtained from Promega (Madison, WI, U.S.A.) and NOF Corporation (Tokyo, Japan), respectively. Deionized and distilled water was used throughout this investigation.

Preparation of $\mathbf{Z n}-\mathbf{M T}-\mathrm{ZnSO}_{4}$ was injected sc into rats at a dose of $20 \mathrm{mg} \mathrm{Zn} / \mathrm{kg} /$ day for 3 days. All rats were killed by exsanguination under ether and livers were removed $24 \mathrm{hr}$ after the last injection. The livers were homogenized in 4 vol. of a $0.25 \mathrm{M}$ sucrose solution. The homogenate containing Zn-MT was centrifuged at $105000 \times g$ for $1 \mathrm{hr}$. The resulting cytosolic fraction was applied to a Sephadex G-75 column $(6.5 \times 80 \mathrm{~cm})$ equilibrated with Tris-HCl buffer (10 mM, pH 8.0), and the column was eluted with the same buffer. The MT fractions were pooled and separated into MT-I and MTII isoforms by ion-exchange chromatography on a DEAE-cellulose column, using a linear gradient of 10-250 mM Tris-HCl, pH 8.0. The fractions, corresponding to Zn-MT-I and II, were concentrated by lyophilization and desalted by gel filtration (Sephadex G-10) with deionized water. The metal concentration in each fraction was measured using an atomic absorption spectrophotometer (AAS, Hitachi 208). Purified Zn-MT samples did not contain any $\mathrm{Cu}$.

Treatment of Salmon Sperm DNA with Fe-NTA/ $\mathbf{H}_{2} \mathbf{O}_{2}$ - Salmon sperm DNA was deionized and precipitated with ethanol three times. In a final volume of $100 \mu \mathrm{l}$, the reaction mixtures contained the following reagents at the final concentrations stated:

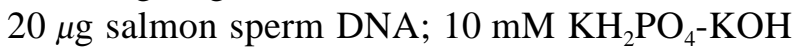
buffer, $\mathrm{pH} 7.4 ; 2.8 \mathrm{mM} \mathrm{H}_{2} \mathrm{O}_{2} ; \mathrm{FeCl}_{3}(0-87.5 \mu \mathrm{M})$; and NTA $(0-350 \mu \mathrm{M})$. NTA and $\mathrm{FeCl}_{3}$ were mixed prior to addition to the reaction mixture. Mixtures were incubated at $37^{\circ} \mathrm{C}$ for $1 \mathrm{hr}$.

\section{Analysis of 8-OHdG for Salmon Sperm DNA -} 8-OHdG levels were measured by a modification of the method of Toyokuni et al. ${ }^{20)}$ DNA in the reaction mixture was precipitated with ethanol twice and then dried by centrifugation under vacuum. After dissolution in $50 \mu \mathrm{l}$ of $1 \mathrm{mM}$ EDTA ( $\mathrm{pH}$ 8.0), the DNA was denatured by heating at $95^{\circ} \mathrm{C}$ for $5 \mathrm{~min}$ followed by rapid chilling. One $\mu \mathrm{l}$ of $2 \mathrm{M}$ sodium acetate (pH 4.5) and $7 \mu \mathrm{l}$ of $5 \mathrm{mg} / \mathrm{ml}$ nuclease $\mathrm{P} 1$ was added and the digest was incubated at $37^{\circ} \mathrm{C}$ for $1 \mathrm{hr}$. Alkaline phosphatase $(15000 \mathrm{U} / \mathrm{ml}, 3 \mu \mathrm{l})$ and $16 \mu \mathrm{l}$ of $1 \mathrm{M}$ Tris- $\mathrm{HCl}(\mathrm{pH} 7.5)$ were added and the reaction incubated at $37^{\circ} \mathrm{C}$ for another $1 \mathrm{hr}$. Finally the DNA solution was filtered through a $0.22 \mu \mathrm{m}$ filter and 
subjected to HPLC/ECD analysis. The HPLC system (Hitachi, Osaka Japan) with a reversed-phase ultrasphere ODS column (particle size $5 \mu \mathrm{m}, 25 \mathrm{~cm}$ $\times 4.6 \mathrm{~mm}$ ) that included both diode array and electrochemical (EC, upstream) detectors (Shodex EC1, Osaka, Japan) connected in series, allowing for simultaneous measurement of dG and 8-OHdG. The mobile phase consisted of $10 \mathrm{mM}$ sodium phosphate containing methanol $(90: 10, \mathrm{v} / \mathrm{v})$, filtered through a $0.45-\mu \mathrm{m}$ filter and degassed. The flow rate was $1.0 \mathrm{ml} / \mathrm{min}$. Identification of each nucleotide peak was confirmed using HPLC with diode array detection and comparison to UV chromophores of standards. The retention time of $\mathrm{dG}$ and $8-\mathrm{OHdG}$ averaged 10.9 and $15.1 \mathrm{~min}$ at $24^{\circ} \mathrm{C}$, respectively. EC detection of $8-\mathrm{OHdG}$ at an applied potential of $800 \mathrm{mM}$ was linear in the nmol range. The content of $8-\mathrm{OHdG}$ and $\mathrm{dG}$ was calculated by comparison to peak areas obtained with respective standards.

\section{Primary Cultures of Rat Hepatocytes — Rats} were injected sc with $\mathrm{ZnSO}_{4}$ at a dose of $20 \mathrm{mg}$ $\mathrm{Zn} / \mathrm{kg} /$ day for 10 days. Parenchymal hepatocytes were isolated from control or $\mathrm{Zn}$-pretreated rats by in situ perfusion of the liver with collagenase. ${ }^{21)}$ Freshly prepared hepatocytes were suspended (density of $1 \times 10^{5}$ cells $/ \mathrm{ml}$ ) in DMEM containing $5 \%$ calf serum, $2 \mathrm{nM}$ insulin, $1 \mathrm{nM}$ dexamethasone, and $20 \mathrm{mg} / \mathrm{l}$ gentamicin sulfate, and were dispensed into all wells of the plate $(5000$ cells/well) or dishes $(1.5$ $\times 10^{6}$ cells). Hepatocytes were maintained at $37^{\circ} \mathrm{C}$ under $5 \% \mathrm{CO}_{2}$ and $95 \%$ air for $24 \mathrm{hr}$. BSO was added at $500 \mu \mathrm{M}$ to the medium $4 \mathrm{hr}$ before treatment with Fe-NTA. The Fe-NTA solution was prepared by the method of Awai et al. to a concentration of $1 \mathrm{mg}$ $\mathrm{Fe} / \mathrm{ml},{ }^{22)}$ and was added to the medium at the indicated concentrations. Six hours following Fe-NTA treatment, the number of viable cells was assessed by Cell Titer 96 Aqueous kit. In order to assay for $\mathrm{dG}$ and 8-OHdG, DNA samples were prepared from monolayers of cells by Blood \& Tissue Genomic DNA Extraction System kit and digested with nuclease P1 and alkaline phosphatase by the same method for salmon sperm DNA. The concentrations of $d G$ in DNA samples were determined by HPLC. The concentrations of $8-\mathrm{OHdG}$ were determined by 8 -OHdG Check ELISA kit because of a low range of cellular 8-OHdG concentrations.

\section{Gel-Filtration of DNA Incubation Mixture -}

Following incubation, five volumes of the DNA reaction mixture was applied to a Sephadex G-75 column $(1.5 \times 28 \mathrm{~cm})$ equilibrated with Tris- $\mathrm{HCl}$ buffer (10 mM, pH 8.0). The column was eluted with the same Tris- $\mathrm{HCl}$ buffer and the eluate was collected in 2-ml fractions. The concentration of $\mathrm{Zn}$ in each fraction was measured by AAS. The concentration of thiol was determined by the Ellman method. ${ }^{23)}$ Statistics - Results are expressed as mean \pm 1 standard deviation (S.D.). Data were analyzed for significance by Student's $t$-test and by a two-tailed analysis of variance (ANOVA). Differences were considered significant at $p<0.05$.

\section{RESULTS}

\section{Effects of MT and GSH on 8-OHdG Formation Induced by Fe-NTA in Vitro}

The ratio of 8-OHdG to dG levels following incubation of salmon sperm DNA with $\mathrm{Fe}^{3+}$ or Fe-chelators in the present of $\mathrm{H}_{2} \mathrm{O}_{2}$ is shown in Fig. 1 . Incubation of DNA with $\mathrm{H}_{2} \mathrm{O}_{2}$ alone did not result in an increase in 8-OHdG levels. However, incubation with $\mathrm{Fe}-\mathrm{NTA} / \mathrm{H}_{2} \mathrm{O}_{2}$ resulted in a dose-dependent increase in 8-OHdG. Neither $\mathrm{Fe}^{3+}$ alone nor the other Fe-chelator complexes tested resulted in an increase in $8-\mathrm{OHdG}$. The ratio of $8-\mathrm{OHdG} / \mathrm{dG}$ after incubation with Fe-NTA was 8 times higher than the ratio with $\mathrm{Fe}^{3+}$ at $12.5 \mu \mathrm{M}$. The effect of $\mathrm{Zn}-\mathrm{MT}$ and

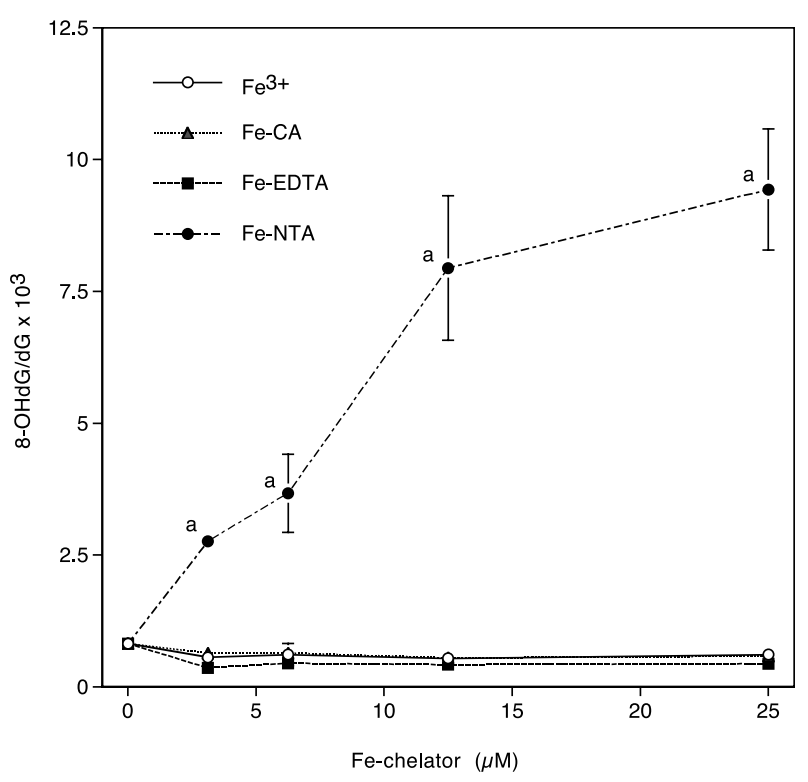

Fig. 1. The 8-OHdG Formation Induced by $\mathrm{Fe}^{3+}$ or Fe-Chelators in DNA with $\mathrm{H}_{2} \mathrm{O}_{2}$

Reaction mixtures contained the following reagents at the final concentrations stated: $20 \mu \mathrm{g}$ salmon sperm DNA, $10 \mathrm{mM} \mathrm{KH}_{2} \mathrm{PO}_{4}-\mathrm{KOH}$ buffer at $\mathrm{pH} 7.4,2.8 \mathrm{mM} \mathrm{H}_{2} \mathrm{O}_{2}, \mathrm{FeCl}_{3}(0-25 \mu \mathrm{M})$ and chelator $(1: 4)$. Data points represent mean \pm S.D. $(n=4)$. a, $p<0.01$, significantly different from Fe-NTA $0 \mu \mathrm{M}$ 


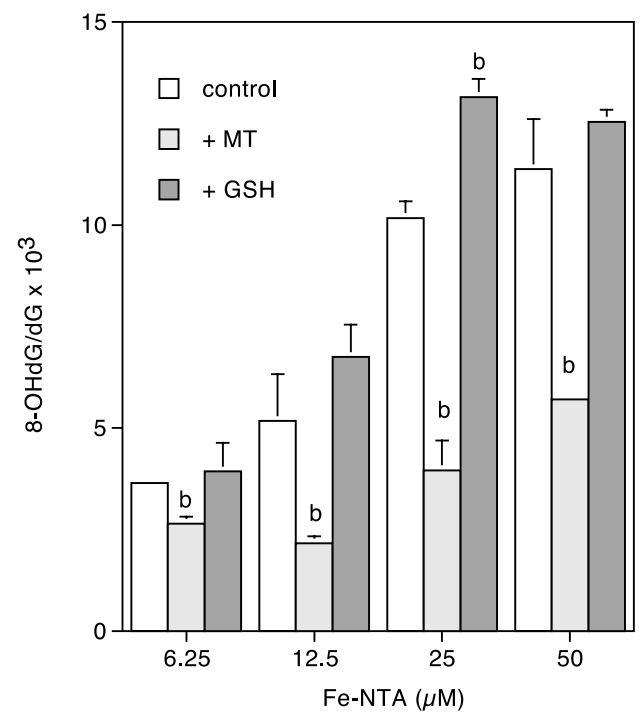

Fig. 2. Effect of MT and GSH on 8-OHdG Formation by Fe$\mathrm{NTA} / \mathrm{H}_{2} \mathrm{O}_{2}$

Purified Zn-MT and GSH was added to same reaction mixtures as in Fig. 1 at final thiol concentrations of $50 \mu \mathrm{M}$. After incubation at $37^{\circ} \mathrm{C}$ for $1 \mathrm{hr}, 8-\mathrm{OHdG}$ was determined by HPLC/ECD. Data points represent mean \pm S.D. $(n=4)$. b,$p<0.01$, significantly different from control group.

GSH, at similar thiol equivalents on the formation of 8 -OHdG induced by Fe-NTA/ $\mathrm{H}_{2} \mathrm{O}_{2}$ is shown in Fig. 2. At each concentration examined, Zn-MT was able to suppress 8-OHdG formation induced by FeNTA by $50 \%$. In contrast, GSH resulted in increased levels of 8-OHdG with Fe-NTA.

Figure 3 shows the gel-filtration profiles of $\mathrm{Zn}$ MT following incubation with Fe-NTA/ $\mathrm{H}_{2} \mathrm{O}_{2}$. The thiol content in MT-containing fractions decreased after the incubation of Zn-MT with Fe-NTA/ $\mathrm{H}_{2} \mathrm{O}_{2}$. Moreover, the concentration of $\mathrm{Zn}$ decreased in the MT fractions and was detected in lower molecular weight fractions, with increasing Fe-NTA. The gel filtration data suggest that incubation of $\mathrm{Zn}-\mathrm{MT}$ with Fe-NTA $/ \mathrm{H}_{2} \mathrm{O}_{2}$ resulted in oxidation of the thiol residues of MT to disulfides and subsequent release of Zn from MT.

\section{Formation of 8-OHdG in DNA Induced by Fe- NTA in GSH-Depleted Primary Cultures of Con- trol and MT-Enriched Hepatocytes}

Cell survival and the level of $8-\mathrm{OHdG} / \mathrm{dG}$ after treatment with Fe-NTA in GSH-depleted primary cultures of hepatocytes prepared from control and $\mathrm{Zn}$-treated rats are shown in Fig. 4A and 4B. MT concentration in hepatocytes prepared from $\mathrm{Zn}$-pretreated rats was 17-times higher that found in hepa-
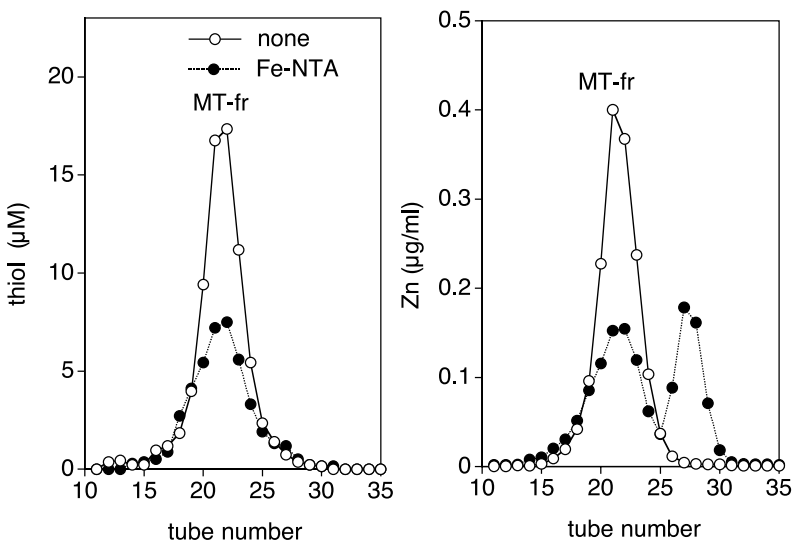

Fig. 3. Loss of the Thiol Residues and Metal Binding Properties of MT Induced by Fe-NTA/ $\mathrm{H}_{2} \mathrm{O}_{2}$ in Vitro

After incubation, five volumes of reaction mixture with MT was applied to a Sephadex G-75 column $(1.5 \times 28 \mathrm{~cm})$ equilibrated with Tris- $\mathrm{HCl}$ buffer $(10 \mathrm{mM}, \mathrm{pH} 8.0)$ and the column was eluted with the same buffer. The concentration of $\mathrm{Zn}$ in each fraction was measured by AAS. The concentration of thiol was determined by Ellman's method.

tocytes prepared from control rats (data not shown). Cellular levels of GSH varied with treatment of $\mathrm{Zn}$ or the concentration of Fe-NTA (data not shown). To clarify whether the cellular MT is involved in resistance to radical-inducing toxicity under the less effective condition of $\mathrm{GSH}$, treatment with $\mathrm{BSO}$, GSH synthesis inhibitor, resulted in a decrease in GSH levels to 5\% of control (data not shown). Treatment with Fe-NTA in the presence of BSO resulted in a significant decrease in cell survival of control cells. MT-enriched hepatocytes demonstrated a resistance to cytotoxicity by Fe-NTA. Moreover, treatment with Fe-NTA caused a significant increase in cellular level of $8-\mathrm{OHdG}$ at $200 \mu \mathrm{M}$ in control cells, but not in MT-enriched cells. It indicates that MT may protect DNA from radicals as a radical scavenger.

\section{DISCUSSION}

Due to a large number of thiol groups in the MT molecule an antioxidant activity has become increasingly more accepted as an important intracellular function of MT. ${ }^{24)}$ While glutathione (GSH) is typically found in cytosol, MT is found both in cytosol and in nucleus. ${ }^{6)}$ The data here suggest that the thiol groups of MT may represent primary targets for nuclear ROS attack, and may act as important free radical scavengers in the cytosol and nucleus.

The DNA base-modified product $8-\mathrm{OHdG}$ is one 

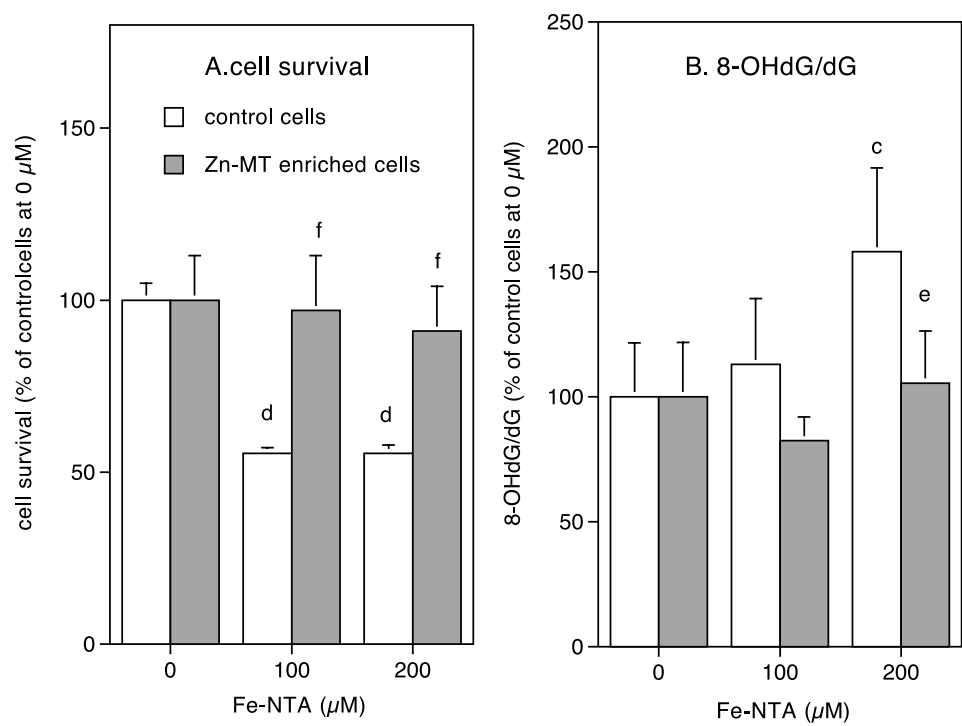

Fig. 4. Cell Survival and 8-OHdG Formation after Treatment with Fe-NTA in the Presence of BSO in Control and MT-Enriched Hepatocytes

The levels of 8-OHdG were measured by ELISA assay at $6 \mathrm{hr}$ after treatment with Fe-NTA. Data points represent mean \pm S.D. $(n=4)$. c, $p<0.05$, d, $p<0.01$, significantly different from control cells at $0 \mu \mathrm{M}$ of Fe-NTA. e, $p<0.05$, f, $p<0.01$, significantly different from control cells at each concentration of Fe-NTA.

of the most commonly used markers for evaluating oxidative DNA damage. ${ }^{16)}$ Moreover, numerous studies have demonstrated that urinary $8-\mathrm{OHdG}$ is not only a biomarker of generalized, cellular oxidative stress, but might also represent a measurable risk factor for other co-morbidities, such as cancer, atherosclerosis and diabetes. ${ }^{25)}$

It was suggested that much of the toxicity of ROS in living organisms is due to the iron-dependent generation of $\cdot \mathrm{OH}$, and/or other powerful oxidants through Fenton chemical reactions. Here, Fe-NTA resulted a marked increase in the $8-\mathrm{OHdG}$ formation after incubation of DNA in the presence of $\mathrm{H}_{2} \mathrm{O}_{2}$, compared to ferric ion and other iron chelators. Therefore, it is shown that Fe-NTA can more efficiently catalyze $\cdot \mathrm{OH}$ production from $\mathrm{H}_{2} \mathrm{O}_{2}$ than $\mathrm{Fe}^{3+}$ or other Fe-chelators. The addition of MT to the incubation mixture resulted in suppression of the 8$\mathrm{OHdG}$ formation by $\mathrm{Fe}-\mathrm{NTA} / \mathrm{H}_{2} \mathrm{O}_{2}$, demonstrating a protective effect. Our previous work has demonstrated that MT can suppress rasDNA strand scission. ${ }^{15)}$ MT may protect DNA from damage by suppressing 8-OHdG formation and DNA strand scission induced by $\bullet \mathrm{OH}$. Therefore, MT may inhibit the $\cdot \mathrm{OH}$ producing process by $\mathrm{Fe}-\mathrm{NTA} / \mathrm{H}_{2} \mathrm{O}_{2}$ or act as a radical scavenger.

Studies have shown that MT-knockout cells were very sensitive to $\mathrm{Cu}-\mathrm{NTA}$, even when the cells were pretreated with $\mathrm{ZnCl}_{2}$. This sensitivity was not seen in cells that overexpressed MT. ${ }^{26)}$ Although Cu-NTA also acts as a pro-oxidant, similar to Fe-NTA, this effect is due to the high affinity sequestration of $\mathrm{Cu}$ by MT. In contrast with $\mathrm{Cu}^{2+}$, gel filtration results found undetectable levels of $\mathrm{Fe}^{3+}$ substituted for $\mathrm{Zn}$ bound to MT under the experimental conditions here. Fe-NTA resulted in a decrease in both thiol concentration and $\mathrm{Zn}$ content in the MT fraction, suggesting that the cysteine thiol groups of MT may be involved in its antioxidant properties. Abel and de Ruiter have demonstrated in vitro that each cysteine residue in MT is 38.5-fold more effective at protecting DNA from $\cdot \mathrm{OH}$ attack than the GSH cysteine. ${ }^{10}$ ) Unlike MT, GSH promoted 8-OHdG formation induced by Fe-NTA here. ESR studies have detected hydroxyl and thiol radicals when Fe reacts with $\mathrm{H}_{2} \mathrm{O}_{2}$ in the presence of GSH, ${ }^{27}$ ) suggesting GSH may not act as an antioxidant in nuclei. A ${ }^{113} \mathrm{Cd}$ NMR study found MT contains two entirely separate metalthiolate clusters, one with four (cluster A) and one with three (cluster B) metal ions, respectively. ${ }^{28}$ Thus, MT cannot produce a thiol-containing radical, unlike GSH. Only Cu-MT may act as a pro-oxidant to release $\mathrm{Cu}^{+}$from $\mathrm{Cu}-\mathrm{MT}$. ${ }^{29)}$ Therefore, MT may act as a radical scavenger in nuclei.

Fe-NTA is a powerful carcinogen and promoter of carcinogenesis in animal models, causing acute nephrotoxicity, renal carcinoma and lipid peroxidation. ${ }^{30)}$ Since an injection of Fe-NTA resulted in a 
significant increase of 8-OHdG in renal DNA, $\cdot \mathrm{OH}$ formation by a reaction of Fe-NTA with $\mathrm{H}_{2} \mathrm{O}_{2}$ in vivo might be involved in the nephrotoxic and renal carcinogenic effects of NTA. ${ }^{19)}$ Here, MT-enriched hepatocytes were resistant to Fe-NTA toxicity during conditions of GSH depletion. Moreover, cellular concentrations of 8-OHdG were significantly decreased in MT-enriched cells compared to control cells. Our recent data have demonstrated that Fe-NTA can result in MT induction, and preinduction of renal MT can attenuate Fe-NTA-induced nephrotoxicity. ${ }^{31)}$ When we considered in conjuction with the current data, we suggest MT may act as an important radical scavenger in the cytosol and nuclei during oxidative stress.

\section{REFERENCES}

1) Chimienti, F., Jourdan, E., Favier, A. and Seve, M. (2001) Zinc resistance impairs sensitivity to oxidative stress in HeLa cells: protection through metallothioneins expression. Free Radic. Biol. Med., 31, 1179-1190.

2) McAleer, M. F. and Tuan, R. S. (2001) Metallothionein protects against severe oxidative stress-induced apoptosis of human trophoblastic cells. In Vitr. Mol. Toxicol., 14, 219-231.

3) Min, K. S., Terano, Y., Onosaka, S. and Tanaka, K. (1992) Induction of metallothionein synthesis by menadione or carbon tetrachloride is independent of free radical production. Toxicol. Appl. Pharmacol., 113, 74-79.

4) Nakagawa, I., Suzuki, M., Imura, N. and Naganuma, A. (1998) Involvement of oxidative stress in paraquat-induced metallothionein synthesis under glutathione depletion. Free Radic. Biol. Med., 24, 13901395.

5) Morcillo, M. A., Rucandio, M. I. and Santamaria, J. (2000) Effect of gamma irradiation on liver metallothionein synthesis and lipid peroxidation in rats. Cell Mol. Biol., 46, 435-444.

6) Woo, E. S., Dellapiazza, D., Wang, A. S. and Lazo, J. S. (2000) Energy-dependent nuclear binding dictates metallothionein localization. J. Cell Physiol., 182, 69-76.

7) Nagano, T., Itoh, N., Ebisutani, C., Takatani, T., Miyoshi, T., Nakanishi, T. and Tanaka, K. (2000) The transport mechanism of metallothionein is different from that of classical NLS-bearing protein. $J$. Cell Physiol., 185, 440-446.

8) Kumari, M. V., Hiramatsu, M. and Ebadi, M. (2000) Free radical scavenging actions of hippocampal metallothionein isoforms and of antimetallothioneins: an electron spin resonance spectroscopic study. Cell Mol. Biol., 46, 627-636.

9) Chubatsu, L. S. and Meneghini, R. (1993) Metallothionein protects DNA from oxidative damage. Biochem. J., 291, 193-198.

10) Abel, J. and de Ruiter, N. (1989) Inhibition of hydroxyl-radical-generated DNA degradation by metallothionein. Toxicol. Lett., 47, 191-196.

11) Cai, L., Koropatnick, J. and Cherian, M. G. (1995) Metallothionein protects DNA from copper-induced but not iron-induced cleavage in vitro. Chem.-Biol. Interact., 96, 143-155.

12) Cai, L. and Cherian, M. G. (2003) Zinc-metallothionein protects from DNA damage induced by radiation better than glutathione and copper- or cadmium-metallothioneins. Toxicol. Lett., 136, 193198.

13) Miura, T., Muraoka, S. and Ogiso, T. (1997) Antioxidant activity of metallothionein compared with reduced glutathione. Life Sci., 60, PL301-PL309.

14) Inoue, S. and Kawanishi, S. (1987) Hydroxyl radical production and human DNA damage induced by ferric nitrilotriacetate and hydrogen peroxide. Cancer Res., 47, 6522-6527.

15) Min, K. S., Nishida, K. and Onosaka, S. (1999) Protective effect of metallothionein to ras DNA damage induced by hydrogen peroxide and ferric ionnitrilotriacetic acid. Chem.-Biol. Interact., 122, 137152.

16) Kasai, H. (1997) Analysis of a form of oxidative DNA damage, 8-hydroxy-2'-deoxyguanosine, as a marker of cellular oxidative stress during carcinogenesis. Mutat. Res., 387, 147-163.

17) De Martinis, B. S. and de Lourdes Pires Bianchi, M. (2002) Methodology for urinary 8-hydroxy-2'deoxyguanosine analysis by HPLC with electrochemical detection. Pharmacol. Res., 46, 129-131.

18) Pirich, C., Pilger, A., Schwameis, E., Germadnik, D., Prufert, U., Havlik, E., Lang, S., Kvaternik, H., Flores, J. A., Angelberger, P., Wanivenhaus, A., Rudiger, H. W. and Sinzinger, H. (2000) Radiation synovectomy using 165Dy ferric-hydroxide and oxidative DNA damage in patients with different types of arthritis. J. Nucl. Med., 41, 250-256.

19) Umemura, T., Sai, K., Takagi, A., Hasegawa, R. and Kurokawa, Y. (1990) Formation of 8-hydroxydeoxyguanosine $(8-\mathrm{OH}-\mathrm{dG})$ in rat kidney DNA after intraperitoneal administration of ferric nitrilotriacetate (Fe-NTA). Carcinogenesis, 11, 345-347.

20) Toyokuni, S., Tanaka, T., Hattori, Y., Nishiyama, Y., Yoshida, A., Uchida, K., Hiai, H., Ochi, H. and Osawa, T. (1997) Quantitative immunohistochemical determination of 8-hydroxy-2'-deoxyguanosine 
by a monoclonal antibody N45.1: its application to ferric nitrilotriacetate-induced renal carcinogenesis model. Lab. Invest., 76, 365-374.

21) Tanaka, K., Sato, M., Tomita, Y. and Ichihara, A. (1978) Biochemical studies on liver functions in primary cultured hepatocytes of adult rats. I. Hormonal effects on cell viability and protein synthesis. J. Biochem. (Tokyo), 84, 937-946.

22) Awai, M. (1978) Intraperitoneal injection of a chelate iron complex salt causes diabetes in rat and rabbits. Nippon Ketsueki Gakkai Zasshi, 41, 1293-300.

23) Suzuki, Y., Lyall, V., Biber, T. U. and Ford, G. D. (1990) A modified technique for the measurement of sulfhydryl groups oxidized by reactive oxygen intermediates. Free Radic. Biol. Med., 9, 479-484.

24) Viarengo, A., Burlando, B., Ceratto, N. and Panfoli, I. (2000) Antioxidant role of metallothioneins: a comparative overview. Cell Mol. Biol., 46, 407-417.

25) Wu, L. L., Chiou, C. C., Chang, P. Y. and Wu, J. T. (2004) Urinary 8-OHdG: a marker of oxidative stress to DNA and a risk factor for cancer, atherosclerosis and diabetics. Clin. Chim. Acta, 339, 1-9.

26) Kawai, K., Liu, S. X., Tyurin, V. A., Tyurina, Y. Y., Borisenko, G. G., Jiang, J. F., St Croix, C. M. Fabisiak, J. P., Pitt, B. R. and Kagan, V. E. (2000)
Antioxidant and antiapoptotic function of metallothioneins in HL-60 cells challenged with copper nitrilotriacetate. Chem. Res. Toxicol., 13, 1275-1286.

27) Spear, N. and Aust, S. D. (1995) Effects of glutathione on Fenton reagent-dependent radical production and DNA oxidation. Arch. Biochem. Biophys., 324, 111-116.

28) Boulanger, Y., Goodman, C. M., Forte, C. P., Fesik, S. W. and Armitage, I. M. (1983) Model for mammalian metallothionein structure. Proc. Natl. Acad. Sci. U.S.A., 80, 1501-1505.

29) Suzuki, K. T., Rui, M., Ueda, J. and Ozawa, T. (1996) Production of hydroxyl radicals by copper-containing metallothionein: roles as prooxidant. Toxicol. Appl. Pharmacol., 141, 231-237.

30) Ebina, Y., Okada, S., Hamazaki, S., Ogino, F., Li, J. L. and Midorikawa, O. (1986) Nephrotoxicity and renal cell carcinoma after use of iron- and aluminum-nitrilotriacetate complexes in rats. J. Natl. Cancer Inst., 76, 107-113.

31) Min, K. S., Morishita, F., Tetsuchikawahara, N. and Onosaka, S. (2005) Induction of hepatic and renal metallothionein synthesis by ferric nitrilotriacetate in mice: the role of MT as an antioxidant. Toxicol. Appl. Pharmcol., 204, 9-17. 